\title{
An Analysis of Oroqen Folk Tales and Their Cultural Value in the Creation of Picture Books*
}

\author{
Zhongfeng $\mathrm{Fu}$ \\ College of Fine Art and Design \\ Heihe University \\ Heihe, China
}

\begin{abstract}
The Oroqen nationality is one of the six small ethnic groups in China. Its natural living environment determines that its basic cultural form has always maintained the characteristics of primitive fishing and hunting culture since ancient times. This cultural form is known as the living fossil of primitive culture in China, so the folk tales and oral culture of the Oroqen nationality have extremely high scientific research value and cultural value. Based on this, this paper takes the legendary story of one of the main forms of the Oroqen folk tales as the research object, elaborates the significance of studying the cultural value of the Oroqen legendary stories in the picture book creation and summarizes the main content of the Oroqen legendary stories. On this basis, this paper explores the cultural value of the Oroqen folk tales in the creation of picture books.
\end{abstract}

Keywords-Oroqen; folk tales; legends; picture book creation; cultural value

\section{INTRODUCTION}

Because it is at a relatively low social development stage, the Oroqen nationality only has its own ethnic language but does not have its own ethnic characters. Therefore, its cultural inheritance is mainly carried out in the form of oral language, which has also determined the artistic form of passing from mouth to mouth of the Oroqen folk tales. Combing and summing up the Oroqen folk tales can make the humanistic value of them known by more people. The legend is a cultural phenomenon that was produced earlier in the history of human development. It embodies human's understanding of themselves and the universe in the early days of human development, and it is a very precious cultural heritage for mankind. As an important literary form to inherit the Oroqen ethnic culture, the picture books need to be further improved and supplemented in the inheriting contents, ways of inheritance, artistic styles, etc. Therefore, the study of Oroqen folk tales and the cultural value of corresponding picture book creation have positive meanings in many aspects.

\section{OVERVIEW OF OROQEN FOLK LEGENDARY STORIES}

Oroqen folk legendary stories are rich in content. Through the collation and research of the existing Oroqen folk legendary stories, it can be found that the rich and unique legendary content and the oral form of inheritance have formed

*Project: This paper is the phased research result of Heilongjiang Province art and science planning project "Oroqen folk tale picture book creation and research", project number: 2017D082. the basic framework of the legendary culture with Oroqen ethnic characteristics. As far as Oroqen folk legendary stories, they are mainly divided into four kinds. First, the legends about the creation of the world: the view of the Oroqen ancestors on the three divisions of the universe reflects their understanding of the importance of self-survival. Heaven, man's world and hell respectively correspond to the upper, middle, and lower levels. People are in the middle of the two and are the center of the universe. And there are legends describing that when the world was in a "chaotic" state, the Jade Emperor sent the mountain god, the rain god, the wind god, etc. to create the earth, lives, mountains and rivers. Through the study of the legends about the creation of the world, we can see the simple world view and profound cultural deposits of the Oroqen ancestors. Second, the legends about the origin of mankind: in the legends of Oroqen, there are many legends describing that God created human, animals changed into human, and the mud was kneaded into human beings. These legends tell how humans were produced and how they were regenerated, which embodies human's spirit of fighting against the nature. Third, the legends about heroes: in these legendary stories, there are mainly heroes who sacrificed themselves to save their clans or tribes, fought with evil forces and devils, sympathized with the laboring people, helped to solve their problems and cure their diseases, and had great loving stories. And the legendary stories about heroes are colorful and rich in content, which embodies the ethics and moral outlook of the Oroqen people to fight with the nature and the society; Fourth, the shaman legends. The Oroqen people have been taking the Shaman culture as their ideological basis. Their folk tales all reflect the ideological connotation of Animism and harmonious coexistence of all things. These legends have been teaching and guiding the Oroqen people from generation to generation. Today, this ethnic culture of harmonious coexistence of all things still has important social and educational significance.

\section{THE CHARACTERISTICS OF THE LEGENDARY STORIES OF OROQEN}

\section{A. Simple Philosophical Thinking}

The legendary stories of Oroqen contain quaint philosophical thoughts. Although it can be seen from the legendary stories which were passed from mouth to mouth that the Oroqen ancestors did not know what philosophy was, they never gave up thinking about and exploring related issues of 
philosophy in the legends about production and life. They expressed their understanding of the world through the most pristine thinking and the most primitive way of communication. First, the cognition that the world was a material world: in the legendary stories of Oroqen, there was a lot of content reflecting the understanding that the world was a material world. Although this kind of understanding is simple and metaphysical, from these expressions about the material world, we can see that the Oroqen ancestors did not be afraid of fear, worked hard and fought hard with nature. For example, the white fog described in the story of "Dagong Shoots the Sun" was made from the burnt ash of the shaft of the twelfth arrow shot by Dagong; The rain and snow in the sky in the story of "The Origin of Rain and Snow" were made from the Jade Emperor's soybean oil and white flour; Humans and birds were made from the birch bark; Bears changed into humans, and so on. These all reflect the meaning of the world is material. Second, the understanding of the unity of opposites: from the legendary stories of Oroqen, we can see that the Oroqen ancestors constructed a relatively stable symmetrical world structure. Most of the materials that made up the world had two poles. All things in the world existed, moved and withered away in the contradictory unity - the word. For example, Endu used the hair and flesh of birds to make ten men and ten women; Dagong shot the sun; The Jade Emperor sent the mountain god, the rain god, and the thunder god to create the materials in the world; and the shaman' s legendary described the heaven, man's world, and the hell. They all reflected the simple philosophical thinking of the Oroqen people. Third, the understanding of causality: from the narrative style of Oroqen legendary stories, we can see that through the use of causality, Oroqen people connected the legendary subjects, and finally made the ending of the story more persuasive. This causality was especially common in the legends about the heroes of Oroqen, reflecting the heroic deeds of Oroqen ancestors who fought against nature, evil forces, and disasters with their wisdom and unyielding character. These understandings have been passed down from mouth to mouth through this kind of intrinsic logical thinking.

\section{B. Romantic Humanistic Spirit}

The legendary stories of the Oroqen reflect its multi-god legendary system. Under the influence of Animism, the expression of the Oroqen on the gods is specific in content, and presents a three-dimensional frame of gods. The play of racial deity and the description of the specific legends make the Oroqen legendary stories romantic and humanistic. And the aesthetic spirit, ethics and morality, cultural values contained in the stories show the longing for the beautiful life of the Oroqen people in the early days, which embodies the guiding significance of this romantic humanistic spirit to the tribes in real life. This humanistic value embodied in the struggle against nature and society still has positive educational significance in today's society.

\section{The Values of the Harmonious Coexistence of All Things}

The Oroqen people take the shamanistic culture of Animism as their ideological basis. The legendary stories about the bears are quite rich. These legends, the Oroqen ancestors' understanding of the bears becoming human beings and the sacrificial rituals of eating bears constitute Oroqen people's relatively complete understanding of bear hunting, eating bears and burying bears, which embodies the folk culture of Oroqen, that is, the contradictory mentality of fighting against nature and peacefully coexisting with nature. This simple contradictory mental state reflects the inner relationship between man and bear, this supernatural relationship itself is the recognition of the concept of harmonious unity of nature, and conveys the values that people and nature need to be harmonious to exist.

\section{The Cultural VAlue OF THE LEGENDARY STORIES OF OROQEN IN THE CREATION OF PICTURE BOOKS}

The legends of the Oroqen are the encyclopedias for the Oroqen people to live. They embody the collective wisdom of the Oroqen ancestors and carry the traditional culture of the entire ethnic group of Oroqen. They are the spiritual support and national symbol of the Oroqen nationality. And they are very precious intangible cultural heritage for human beings. By recognizing and studying the legendary stories of the Oroqen, we can continue to carry forward and promote the intrinsic cultural and social values. At the same time, we can also spread the good parts in the Oroqen legends to people's social life for development and utilization, making the unique Oroqen ethnic culture fully played. For example, the creation of picture books is not only a literary carrier for recording the legends of the Oroqen. Through the careful selection of the legends and the detailed understanding of the ethnic costumes and decorations of the Oroqen, we can also make Oroqen folk legends have social educational significance. The cultural values of Oroqen folk legends in the creation of picture books are mainly reflected in the following two aspects.

\section{A. The Oroqen Folktales Are the Source of the Creation of the Picture Books}

First, the Oroqen folktales are rich in subject matter and are unique. Oroqen folktales are extensive and rich in subject matter from the creation of the world to the Oroqen heroes. And there is the unique fishing and hunting culture of Oroqen in the legends, which can provide many materials and inspirations for the current domestic picture book creation, thus enriching domestic picture book creation which is based on China's local culture and promoting the continuous development of the picture book creation industry in China. Second, it is needed to advance with the times and inherit the excellent national culture. With the continuous development of domestic picture book creation and the continuous improvement of people's tasting level for painting works, the Chinese picture book creation with the themes of national culture has been awakened. While absorbing a large number of foreign experiences in the creation of classic excellent picture books, we should intensify the creation of the picture books about the Oroqen folk tales, and develop the cultural value of Oroqen folk culture. This is not only an innovative path for the creation of picture books in China, but also the needs of inheriting the Oroqen national culture and even the entire Chinese civilization. Third, the Oroqen folk tales contribute to the innovation of picture book creation. The Oroqen folk legends have rich themes, profound cultural deposits, and unique ethnic costumes and local customs, which is very inspiring for the current artistic conception of domestic picture 
book creation. As far as the artistic conception of domestic picture book creation, the themes are too singular, there is a lack of story structure ability and there are space limitations in the narration of stories. Based on these, the Oroqen folk legends can well fit the current artistic conception ability of domestic picture book creation, helping the authors of the picture books to broaden creative ideas and draw and adapt excellent materials.

\section{B. The Inheritance of Oroqen Folk Culture Carried out by the Creation of Picture Books}

Folk legends have always been an important subject of picture book creation, and are an indispensable part in picture book publishing. It is not only because the folk legends have a wide range of themes and are easy to select the topic and create, but also because the folk legends contain some excellent national traditional culture and are indispensable parts of the national complex and the inheritance of civilization. As far as the Oroqen folk legends, they are an important branch of the inheritance of Chinese civilization. Inheriting the Oroqen folk legends can not only enhance readers' perception of traditional national art, but also deepen readers' cognition of traditional folktales, and at the same time enrich readers' emotional experience of traditional folk culture. Of course, since most of the picture books are designed and created for the children, we must have an inherited attitude as well as a critical principle and understanding towards the Oroqen folk legends. When introducing the folk legends to children, we should not introduce them all to the children just because the stories are the legacies of the Oroqen ancestors. Instead, we should first think about questions from the perspective of children. Does this story have any literary value for children? Is there any guiding significance? Only in this way can the Oroqen folktales really play a role in educating children.

\section{CONCLUSION}

The proverb "Those who cannot hunt are not considered to be Oroqen." fully reflects the national characteristics of the Oroqen nationality, which also determines that its folk legends have been passed down taking hunting and fishing as the foundation. But the variation, fusion and dissipation of culture are all inevitable. With Oroqen people's downhill settlement and the involvement of foreign cultures, the Oroqen national culture is suffering unprecedented erosion, and how to inherit the cultural value embodied in its folk stories has also become the primary problem that needs to be solved urgently in current intangible cultural heritage protection and national cultural heritage. Therefore, studying the cultural value of the creation of Oroqen folk story picture books, and displaying the morals of the Oroqen folk tales, the unique customs and national culture in the picture books to inherit and protect the folk culture of Oroqen can make the ethnic culture, ethnic symbol and even the ethnic spirit of Oroqen be retained.

\section{REFERENCES}

[1] Fu Zhongfeng. Research on the Current Situation of the Creation of Oroqen Folklore Picture Books [J]. Northern Lights, 2018(03) (in Chinese)
[2] Wang Bingzhen. Research on the Aesthetic Culture of the Oroqen Nationality [D]. Heilongiiang University, 2014. (in Chinese)

[3] Namin, Du Jiandong. Research on the inheritance status of "Mosukun"[J]. Journal of The Beifang University Of Nationalities (Philosophy and Social Sciences Edition), 2012 (03): pp.63-68. (in Chinese)

[4] Sun Guisen, Zhao Guangxing. The History of Oral Inheritance - On the Folk Literature of the Oroqen Nationality[J]. Journal of Inner Mongolia University for Nationalities(Social Sciences), 1988 (04): pp.19-22. (in Chinese)

[5] Ma Mingchao. New Discoveries in Folk Literature of Chinese Northern Nationalities - On the Oroqen Epic "Mosukun"[J]. Study \& Exploration , 1988 (01): pp.121-124. (in Chinese) 